Resona Jumal Ilmiah Pengabdian Masyarakat Vol. 2, No. 1 (2018) 38-46

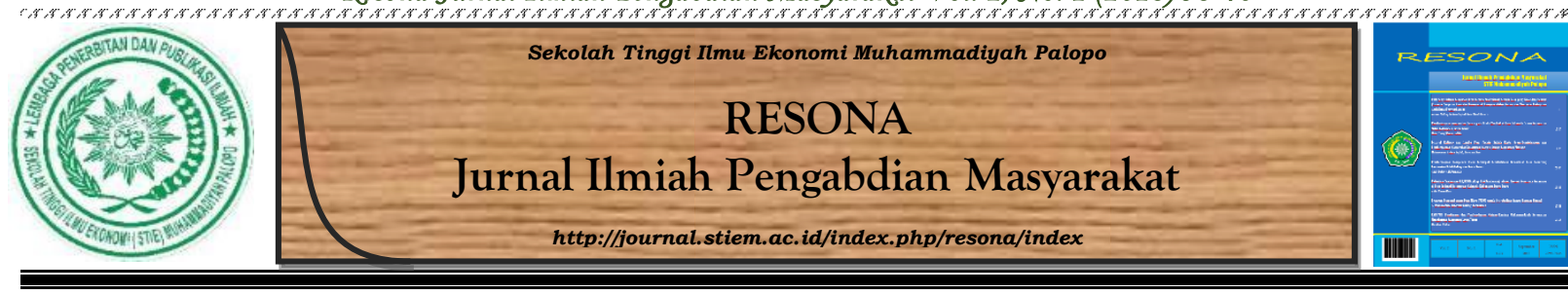

\title{
Pelatihan Pembuatan KOJIRAMA (Kopi Biji Rambutan) sebagai Inovasi Kekayaan Nusantara di Desa Ladongi Kecamatan Malangke Kabupaten Luwu Utara
}

\author{
Abid Ramadhan ${ }^{1}$, Andi Nurul Mukhlisah ${ }^{2}$ \\ ${ }^{1,2}$ Sekolah Tinggi Ilmu Ekonomi Muhammadiyah Palopo
}

\section{INFO NASKAH}

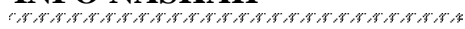
Diserahkan

7 Agustus 2018

Diterima

8 Agustus 2018

Diterima dan disetujui

8 Agustus 2018

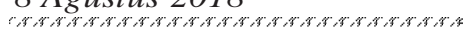

\section{Kata Kunci:}

Biji rambutan

Desa ladongi

Inovasi

Kojirama

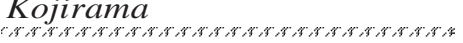

\begin{abstract}
ABSTRAK Kopi merupakan salah satu komoditas ekspor yang baik di Indonesia menjadi negara ketiga dunia yang unggul dalam kualitas kopinya. Begitu banyak kopi yang terkenal di Indonesia seperti kopi toraja, kopi luwak, kopi aceh, dan sebagainya. Namun dilihat dari segi kesehatan, ternyata kopi tidak selamanya memberikan efek baik bagi kesehatan manusia dikarenakan senyawa kafein yang ada di dalam kopi menjadi penyebab berbagai macam penyakit. Oleh karena itu, saat ini sudah berkembang berbagai macam alternatif pengolahan kopi, namun bukan menggunakan biji kopi yang umumnya digunakan tetapi menggunakan bahan lain seperti biji pepaya, biji salak, dan biji rambutan. Metode yang digunakan dalam pengabdian ini adalah pelatihan-pelatihan yang dilakukan dalam kegiatan KKN-PPM dengan sasaran utamanya adalah BUMDes dan masyarakat Desa Ladongi Kecamatan Malangke. Pelatihan ini bertujuan untuk memberikan pengetahuan dan keterampilan warga dalam mengolah biji rambutan menjadi kopi bubuk yang nantinya akan dikembangkan dan dipasarkan oleh BUMDes. Hasil pelatihan ini diharapkan dapat meningkatkan pendapatan warga dalam memanfaatkan biji rambutan yang awalnya tidak bernilai dan hanya dibuang begitu saja menjadi komoditas unggulan dan bernilai ekonomis.
\end{abstract}

\section{Pendahuluan}

Menurut firman (2012), kopi merupakan minuman berwarna hitam gelap dengan aroma khas yang biasanya diseduh menggunakan air panas dan pada dasarnya memiliki rasa pahit. Minuman kopi banyak digemari hampir seluruh masyarakat dunia. Aroma dan rasa yang khas pada kopi seringkali membuat para penikmat kopi merasa kecanduan. Kopi masuk ke Indonesia dibawa oleh pedagang dari timur tengah. Kopi memiliki rasa yang berbeda di tiap daerah disebabkan oleh perbedaan iklim dan cara pemrosesan kopi hingga terciptanya kopi 
yang berkualitas.

Saat ini, peningkatan produksi kopi di Indonesia masih terhambat oleh rendahnya mutu biji kopi yang dihasilkan sehingga hal ini mempengaruhi pengembangan produksi akhir kopi. Hal ini disebabkan karena penanganan pasca panen yang tidak tepat antara lain proses fermentasi, pencucian, sortasi, pengeringan, penyangraian, dan spesifikasi alat/mesin yang digunakan. Selain itu, dengan masih rendahnya mutu biji kopi dan kendala-kendala lain yang telah dijelaskan, hal ini perlu adanya inovasi dan peneltian alternatif guna memberikan temuan baru mengenai pembuatan kopi yang bukan berasal dari biji kopi. contohnya kopi yang terbuat dari biji salak, petai cina, biji rambutan, dan sebagainya.

Indonesia merupakan negara yang beriklim tropis yang menandakan bahwa keadaan di suatu wilayah memiliki suhu yang lembab dan hangat, baik sepanjang tahun maupun pada bagian musim tertentu. Iklim tropis di indonesia ini memiliki keuntungan khususnya dalam bidang pertanian dengan manfaat untuk penanaman buah atau dikenal dengan istilah buah tropika. Salah satu buah yang termasuk dalam kategori buah tropika adalah rambutan. Rambutan memiliki waktu pemanenan sekitar bulan November hingga Februari, selain itu disesuaikan juga dengan intensitas musim kemarau atau musim penghujan di Indonesia (Kiswanto, 2013). Pada waktu panen rambutan, orang-orang yang mengonsumsi rambutan hanya sebatas buahnya saja. Sementara kulit dan bijinya tidak dikonsumsi dan dibuang begitu saja. Sehingga menimbulkan sampah dan menjadi limbah yang menyebabkan polusi lingkungan.

Rambutan merupakan salah satu spesis tumbuhan yang berpotensi untuk dikembangkan sebagai obat herbal. Hal tersebut dikarenakan pada rambutan banyak mengandung metabolit sekunder yang memiliki banyak aktivitas farmakologi dalam mengatasi berbagai penyakit. (Bone dan Mills, 2013). Bagian rambutan yang memiliki banyak manfaat adalah kulit dan biji rambutan yang biasanya dibuang segitu saja. Kandungan dari kulit rambutan memiliki beberapa senyawa organik, salah satunya asam galat. Menurut penelitian yang dilakukan sebelumnya, senyawa tersebut dapat membawa radikal bebas keluar tubuh sehingga bisa menghindarkan tubuh dari kerusakan dan meningkatkan anti kecemasan. Kulit rambutan memiliki kandungan antioksidan yang tinggi, dinamakan flavonoid (Runestad, 2009). Flavonoid dapat berperan dalam menghindari risiko kanker dan baik untuk mengurangi kadar kolesterol dalam gula darah (Desideria, 2015). Selain itu, biji rambutan mengandung flavonoid dan fenolik yang dapat digunakan untuk mengobati diabetes. 
Bahan lainnya yang memiliki banyak kandungan gizi adalah beras ketan hitam. Beras ketan hitam merupakan varietas lokal yang mengandung pigmen paling baik dibandingkan beras putih atau beras warna lainnya. Beras hitam merupakan salah satu jenis beras yang mulai populer di masyarakat dan dikonsumsi sebagai pangan fungsional karena bermanfaat bagi kesehatan. Salah satu potensi beras ketan hitam adalah kandungan seratnya yang sangat tinggi. Kandungan serat pada makanan bermanfaat dalam mencegah risiko penyakit jantung, diabetes, dan membantu memperlancar pencernaan.

Beras ketan hitam menjadi salah satu bahan pangan lokal yang sering digunakan sebagai bahan baku dalam pembuatan kue basah atau jajanan pasar. Penggunaan beras ketan hitam sampai saat ini masih terbatas dalam bentuk tepung sehingga perlu dilakukan pemanfaatan dalam produk lain yang digemari banyak orang sebagai upaya diversifikasi pangan lokal, salah satunya dalam campuran pembuatan kopi biji rambutan. Ketan hitam dipilih karena potensi antosianin sebagai antioksidan pada tepung beras ketan hitam. Antosianin adalah komponen warna utama dalam bahan pangan yang dapat menimbulkan warna ungu, biru hingga merah kehitaman. Mengkonsumsi antosianin terbukti mampu memberikan efek perlindungan terhadap penyakit kardiovaskular (Oki et al., 2002; wang dan stoner, 2008), diabetes mellitus (Matsui et al., 2002), anti inflamasi (Kano et al., 2005), dan anti kanker (Bagchi et al., 2004).

\section{Masalah}

Minuman kopi yang umum dikonsumsi oleh masyarakat adalah olahan dari biji kopi, yang memiliki kandungan nutrisi seperti karbohidrat (60\%), protein (13\%), asam lemak seperti asam linoleat $(39 \%)$, asam stearat $(13,1 \%)$, asam oleat $(17,2 \%)$, asam arachidat $(4,2 \%)$, asam palmitat $(25,3 \%)$, asam behenat $(1 \%)$, kafein arabika $(1,0 \%)$ dan robusta $(2,0 \%)$ (Simanjutak, 2011). Salah satu nutrisi biji kopi yang tidak baik untuk kesehatan jika dikonsumsi secara berlebihan adalah kafein.

Kafein tergolong dalam keluarga methylxanthine bersama-sama senyawa tefilin dan teobromin berlaku sebagai penenang sistem saraf pusat. Adapun dampak negatif dari kafein yaitu dapat menyebabkan pengerasan dinding arteri yang mengganggu kinerja jantung, mengalami kekhawatiran kronis, gelisah, dan lekas marah (keracunan kafein), menimbulkan gangguan mental jika dikonsumsi secara berlebihan, meningkatkan resiko osteophorosis (Nurdiana dan Nelly, 2013). Selain itu, mitra kami di Desa Ladongi memiliki banyak pohon rambutan namun biji rambutannya tidak dimanfaatkan sehingga tidak menghasilkan nilai 
ekonomis padahal jika diinovasikan, biji rambutan bisa dijadikan kopi yang nikmat tanpa kandungan kafein. Inovasi tersebut diharapkan dapat memberikan kontribusi dalam dunia perkopian untuk menciptakan dan memperkenalkan kopi nonkafein sebagai bagian dari kreatifitas masyarakat.

\section{Metode Pelaksanaan}

Metode yang digunakan dalam kegiata ini adalah melalui pelatihan. Pelatihan merupakan bagian dari pendidikan yang menyangkut proses belajar untuk memperoleh dan meningkatkan keterampilan di luar sistem pendidikan yang berlaku, dalam waktu yang relatif singkat dan dengan metode yang lebih mengutamakan praktik daripada teori. Menurut Widodo (2015:82), pelatihan merupakan serangkaian aktivitas individu dalam meningkatkan keahlian dan pengetahuan secara sistematis sehingga mampu memiliki kinerja yang profesional di bidangnya. Pelatihan adalah proses pembelajaran yang memungkinkan pegawai melaksanakan pekerjaan yang sekarang sesuai dengan standar. Tujuan diadakannya pelatihan ini adalah untuk:

a. Peningkatan partisipasi masyarakat di Desa Ladongi. Program KKN-PPM ini nantinya diharapkan masyarakat dapat antusias dalam mengelola biji rambutan menjadi kopi bubuk nonkafein.

b. Peningkatan pendapatan masyarakat. Melalui program KKN-PPM ini juga diharapkan masyarakat dapat membuat usaha secara mandiri dari swadaya masyarakat sendiri tanpa bergantung pada bantuan Pemerintah Kabupaten Luwu Utara. Jika hal ini dapat tercapai, maka juga akan menambah penghasilan masyarakat yang berujung pada peningkatan kesejahteraan masyarakat.

\section{Hasil dan Pembahasan}

Program pengabdian kepada masyarakat ini telah berjalan lancar sesuai dengan yang direncanakan.

\section{Luaran Utama dalam Pemecahaan Masalah}

Luaran dalam pengabdian ini adalah produk kopi biji rambutan yang dicampur menggunakan ketan hitam dan memiliki berbagai varian rasa seperti jahe, serai, dan vanilla. Kemudian publikasi melalui jurnal online dan hak kekayaan intelektual (HAKI) diperlukan untuk melindungi hasil karya dan karsa yang dimiliki atau diciptakan. 


\section{Kelebihan dan Kelemahan}

Kelebihan produk ini merupakan hal baru di Kabupaten Luwu Utara sebab masyarakat yang ada di sana belum banyak yang mengetahui jika biji rambutan dapat diolah dan mempunyai kandungan gizi yang baik untuk mengobati berbagai macam penyakit. Selain itu, di Luwu Utara merupakan daerah yang mempunyai banyak pohon rambutan sehingga bahan baku sangat melimpah. Kekurangan, rambutan merupakan buah musiman sehingga sulit untuk mendapatkan bahan baku berupa biji rambutan jika tidak musim, oleh karena itu perlu adanya menyimpanan biji rambutan dalam jumlah yang banyak.

\section{Tantangan dan Kesulitan}

Tantangan utama dalam pelatihan kopi biji rambutan (KOJIRAMA) adalah masih kurangnya edukasi masyarakat terhadap manfaat dan cara mengolah biji rambutan sehingga inovasi ini belum terlalu diminati karena faktor belum terpublikasi sehingga kedepannya dengan melalui pelatihan KKN-PPM ini dan kegiatan lainnya diharapkan bisa dikenal masyarakat dan menjadi produk khas Luwu Raya yang mempunyai pangsa pasar sendiri. Selain itu, saat pertama kali dipublikasikan produk ini di masyarakat, masih terkendala minat masyarakat yang kurang untuk berpartisipasi mengikuti pelatihan yang dilakukan di Desa Ladongi dan juga lokasi pelatihan sangat jauh dan memiliki medan yang kurang baik.

\section{Dokumentasi}

Bahan baku yang digunakan adalah bahan utama yang terdiri dari biji rambutan dan beras ketan hitam, bahan tambahan seperti jahe dan serai.
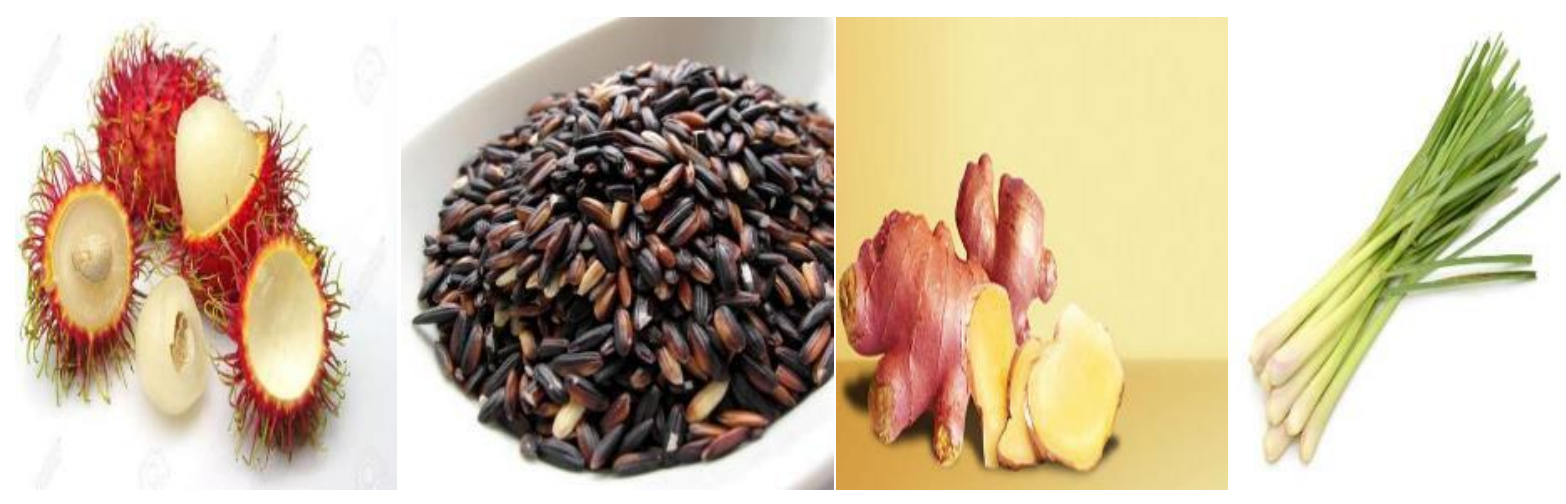

Adapun proses dari pembuatan kopi biji rambutan ini dijelaskan sebagai berikut:

a. Siapkan alat dan bahan yang terdiri dari wajan tanah, kompor, pasir, saringan penggorengan, tapis, blender, dan plastik kemasan.

b. Nyalakan kompor dan panaskan wajan kemudian masukkan beras ketan hitam terlebih 
dahulu dan disangrai.

c. Setelah itu sangrai juga jahe dan serai yang sebelumnya telah di jemur.

d. Angkat semua bahan tadi dan tiriskan. Setelah itu, masukkan pasir yang sebelumnya telah dicuci dan di tiriskan.

e. Masak pasir hingga panas kemudian masukkan biji rambutan.

f. Sangrai hingga kecoklatan kemudian saring biji rambutan untuk memisahkannya dengan pasir.

g. Setelah itu tiriskan dan blender satu persatu bahan yang telah matang dimulai dari ketan hitam, jahe, serai, dan terakhir kopi biji rambutan.

h. Bahan baku yang telah diblender kemudian ditapis untuk mendapatkan bubuk yang halus.

i. Setelah itu campur semua bahan dengan berat bersih 200 gram dengan rincian 150 gram kopi biji rambutan, 40 gram ketan hitam, dan 10 gram jahe atau serai.

j. Kemudian kemas dan siap di pasarkan.

Berikut ini dokumentasi proses pembuatan kopi biji rambutan:

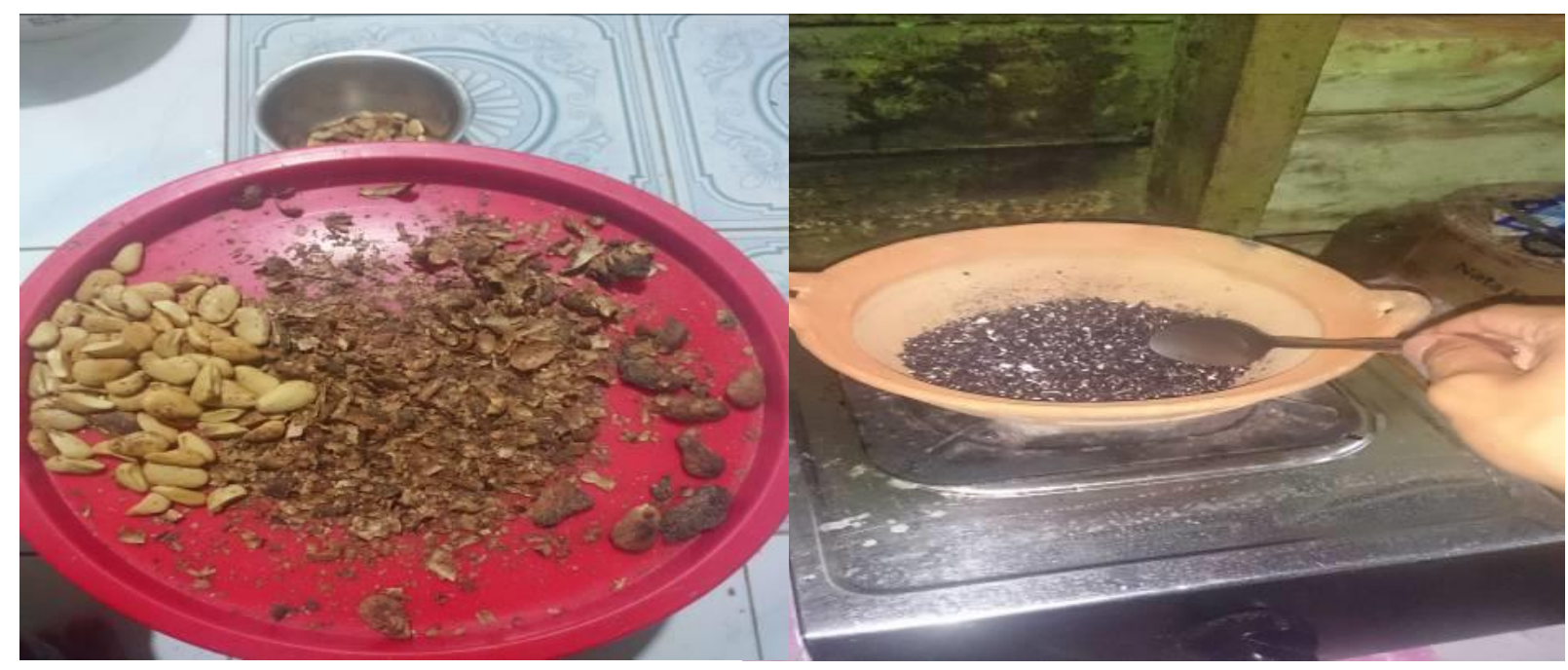



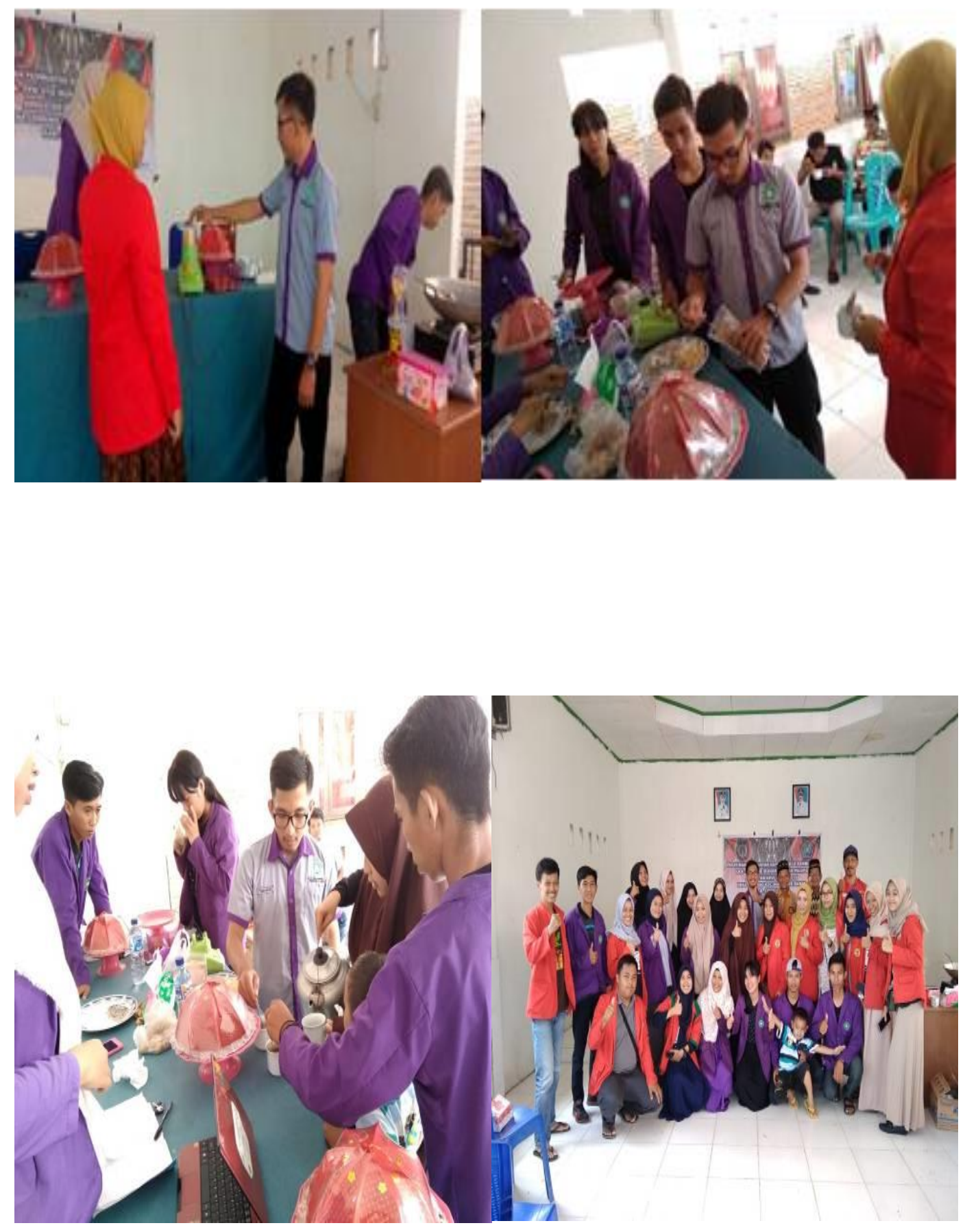


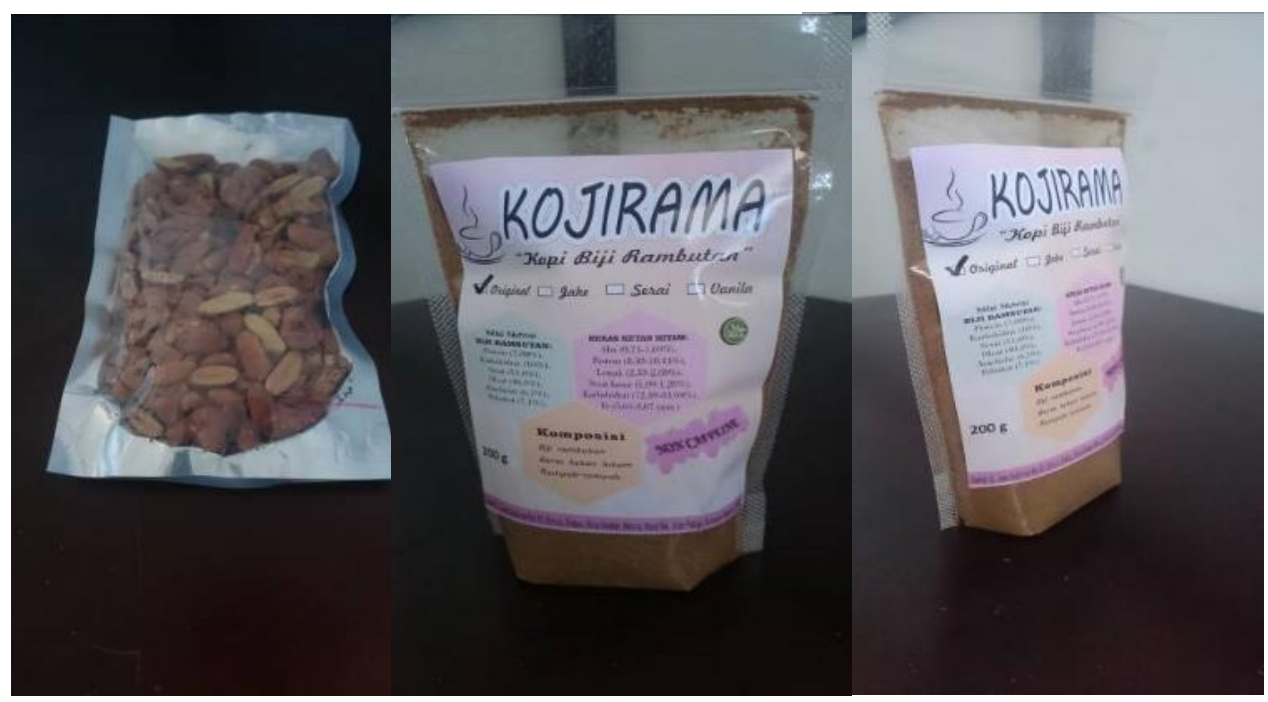

\section{Simpulan dan Saran}

Biji rambutan merupakan biji yang memiliki beragam khasiat seperti mencegah diabetes, mengatasi penyakit kencing manis, anti bakteri, menyehatkan saluran kemih, mencegah penyakitan ayang-anyang, mengatasi sariawan, antioksidan, mengatasi kanker, meningkatkan imun tubuh, melancarkan system pencernaan, baik untuk kesehatan kulit, mengatasi penuaan dini, mengatasi jerawat, dan mencerahkan kulit. Biji rambutan dapat diolah dalam berbagai produk seperti kopi biji rambutan, emping rambutan, tepung biji rambutan, dan minyak biji rambutan. Bahkan dalam referensi yang lain, bukan hanya biji rambutan saja yang dapat dimanfaatkan namun daun, kulit, dan buah rambutan.

Kurangnya produksi bisnis dan melimpahnya biji rambutan ketika sedang musim di Luwu Utara serta manfaat yang banyak dari biji rambutan, diharapkan masyarakat khususnya di Luwu Utara lebih giat dalam mengembangkan produk yang berasal dari biji rambutan sehingga di kemudian hari produk ini dapat menjadi peluang bisnis yang menjanjikan.

\section{Daftar Pustaka}

Abe, T., M. Kano, dan T. Sasahara. 2005. Quantitative Difference of 7s Globulin on Vegetable Soybean Seeds. Journal of the Japanese Society for Food Science and Technology 52 (3): 107-113.

Bagchi, D., C.K. Sen, M. Bagchi, dan M. Atalay. 2004. Anti-angiogenic, Antioxidant, and Anti-carcinogenic Properties of a Novel Anthocyanin-Rich Berry Extract Formula. Biochemistry (Moscow) 69 (1): 75-80. 
Bone, K., dan S. Mills. 2013. Principles and Practice of Phytotherapy. Second Edition. Churchill Livingstone Elsevier. New York.

Daswin, N.B.T., dan N.E. Samosir. 2013. Pengaruh Kafein terhadap Kualitas Tidur Mahasiswa Fakultas Kedokteran Universitas Sumatra Utara. E-Jurnal FK USU 1 (1).

Desideria, B. Tak Cuma Manggis, Kulit Rambutan pun Bermanfaat bagi Kesehatan. http://health.liputan6.com/read/2160020/tak-cumamanggis-kulit-rambutan-punbermanfaat-bagi-kesehatan.

Firman. 2011. Analisa Kopi. http://www.gedoor.com/wpcontent/uploads/2011/Analisa Kopipublish. 25 April 2018. (12.15).

Inoue, Y., T. Osawa, A. Matsui, Y. Asai, Y. Murakami, T. Matsui, dan H. Yano. 2002. Changes of Serum Mineral Concentration in Horses during Exercise. Asian Austr $J$ Anim Sci 15 (4): 531-536.

Kiswanto. 2013. Musim Panen Raya Buah Rambutan Harga Jualnya Rendah. http://www.klaten.info/berita/musim-panen-raya-buah-rambutan-hargajualnyarendah.html.

Oki, T., M. Masuda, M. Kobayashi, dan T. Sato. 2003. Polymeric Proanthocyanidin as Radical-Scavenging Component in Red Hulled Rice. Journal of Agriculture and Food Chemistry 50 (26):7524-9.

Runestad, T. 2009. Superfruits: Elevate Antioxidant Claims. Functional Ingredients. http://search.proquest.com/docview/220815829? accountid $=44945$.

Simanjuntak, R.E.V. 2011. Artikel Ilmu Bahan Makan dan Bahan Penyegar Kopi. Fakultas Kedokteran Universitas Diponegoro. Semarang.

Wang, L.S. dan G.D. Stoner. 2008. Anthocyanins and Their Roles in Cancer Prevention. Cancer Letters 269 (2): 281-290. 